\title{
IgE AND IgG ANTIBODY RESPONSES TO Dermatophagoides pteronyssinus IN DOGS WITH DEMODICOSIS AND ATOPIC DERMATITIS
}

\author{
RESPOSTAS DE ANTICORPOS IgE E IgG ESPECÍFICOS À DERMATOPHAGOIDES \\ PTERONYSSINUS EM SOROS DE CÃES COM DEMODICOSE E DERMATITE \\ ATÓPICA
}

\author{
Maria Cecília OLIVEIRA ${ }^{1}$; Ana Cláudia Arantes Marquez PAJUABA ${ }^{2}$; \\ José Eugênio Diniz BASTOS ${ }^{3}$; José Roberto MINEO ${ }^{2}$; Fabiana Parreira SOUZA ${ }^{2}$; \\ Ester Cristina Borges ARAUJO ${ }^{1}$; Marcos Paulo Oliveira ALMEIDA ${ }^{\mathbf{1}}$; \\ Deise Aparecida Oliveira SILVA ${ }^{2}$; Ernesto Akio TAKETOMI ${ }^{2}$; Neide Maria SILVA ${ }^{1}$
}

1. Federal University of Uberlândia, Institute of Biomedical Sciences, Department of Cell Biology, Histology and Embryology, Uberlândia, MG, Brazil; 2. Federal University of Uberlândia, Department of Immunology, Institute of Biomedical Sciences, Uberlândia, MG, Brazil; 3. Federal University of Uberlândia, Department of Animal Medicine, Faculty of Veterinary Medicine, Uberlândia, MG, Brazil.nmsilva@ufu.br

\begin{abstract}
Canine demodicosis is a common inflammatory parasitic skin disease caused by Demodex mites. House dust mites, such as Dermatophagoides spp., play an important role in the pathogenesis of canine atopic dermatitis (AD). The goal of this experimental work was to investigate whether demodectic dogs could be previously exposed/sensitized to house dust mites' antigens. First the prevalence of demodicosis in a southeastern region of Brazil was investigated by analyzing clinical files of dogs that were admitted to a Veterinary Hospital. Subsequently, the IgG responses to Dermatophagoides pteronyssinus (Dp) and Dermatophagoides farinae (Df) and IgE to D. pteronyssinus (Dp) were evaluated in two groups, $\mathrm{AD}$ or demodicosis dogs. Additionally, the major IgE-binding Dp proteins that are recognized by sera from dogs with demodicosis and $\mathrm{AD}$ were evaluated. A total of 2,599 clinical files were analyzed to identify the major parasitic skin diseases in dogs from this region, considering the age, sex and breed of the animals. The epidemiological study identified 111 animals with skin diseases; from these $20.7 \%$ presented demodicosis. Afterwards, serum samples were obtained from another groups of demodicosis, AD, and healthy dogs, and analyzed for Dp and Df-specific IgG, and IgE antibody levels, Dp IgG avidity by ELISA and IgE-binding Dp-specific proteins by immunoblot. IgG and IgE antibodies to $\mathrm{Dp}$ were detected in sera from additional groups of dogs with $\mathrm{AD}$, demodicosis or healthy, with higher IgE levels to Dp in AD than demodectic or healthy dogs. IgG to Df was detected, despite with smaller levels compared to Dp in sera from demodectic dogs, and also in healthy dogs. Immunoblot showed IgE-binding to Dp proteins in sera of dogs with demodicosis and $\mathrm{AD}$; with strong reactivity for the 72 and $116 \mathrm{kDa}$ antigens detected by sera from demodicosis dogs. However, sera from healthy dogs $>12$ months old also presented reactivity to these bands. In conclusion, the detection of Dp-IgG and IgE antibodies in sera from demodectic dogs indicates previous exposure and sensitization to the house dust mite, respectively, more than cross-reactivity between demodex mites and Dp antigens detected by canine antibodies. Additionally, higher Dp-specific IgE levels were found in dogs with AD compared with those with demodicosis or healthy, suggesting that Dp-specific IgE could better discriminate dogs with AD from healthy ones or even those with demodicosis.
\end{abstract}

KEYWORDS: Demodex canis. Demodicosis. Dermatophagoides pteronyssinus. Dogs. IgG. IgE

\section{INTRODUCTION}

Canine demodicosis is a common parasitic skin disease resulting from excessive proliferation of the commensal mite Demodex canis within the hair follicles (KWOCHKA, 1987). Demodex canis may occur in small numbers as part of the normal fauna of the canine skin and can also be found in healthy dogs (SHIPSTONE, 2000). The mites on the skin are transmitted from the bitch to their nursing puppies within the first days after birth (GREEVE;
GAAFAR, 1966). According to the extent of the disease, demodicosis is classified as either localized or generalized. Localized demodicosis is a benign disease that generally resolves spontaneously and is not normally associated with concurrent bacterial pyoderma. In contrast, generalized demodicosis is considered one of the most severe canine skin diseases and mostly involves secondary bacterial skin infections, which require administration of systemic antibiotics concomitantly with acaricidal treatment (PARADIS, 1999; MUELLER, 2004). In 
many countries, $D$. canis has been reported as the most important infestation of mange mites in dogs (NAYAK et al., 1997; CHOI; LEE; LEE, 2000), particularly in stray dogs (RODRIGUEZ-VIVAS et al., 2003).

The pathogenesis of demodicosis is not yet fully understood. It is believed that the disease results from the inability of the host to regulate a high number of mite burden rather than an increase in mite virulence. There is evidence suggesting that the excessive proliferation of Demodex mites may be due to an underlying genetic or immunological disorder in the affected dogs and that the tendency to develop demodicosis has a hereditary basis (SHIPSTONE, 2000). Previous studies have shown that dogs with generalized demodicosis present an imbalance in $\mathrm{T}$ cells in the blood, with decreased CD4+ $\mathrm{T}$ cells and increased $\mathrm{CD} 8+\mathrm{T}$ cells, in addition to a reduced $\mathrm{CD} 4+/ \mathrm{CD} 8+$ ratio compared with healthy controls (OLIVEIRA; LARSSON; DE CAMARGO, 2015; REDDY; SIVAJOTHI, 2016). Also, dogs suffering recurring from recurrent demodicosis have high levels of IL-10 production (FELIX et al., 2013). Dogs with generalized demodicosis suffer from an immune dysfunction that has been called antigen-specific effector T-cell exhaustion (reviewed by FERRER; RAVERA; SILBERMAYR, 2014). On the other hand, there are very few studies focusing on the humoral immune response against Demodex mites. A recent study showed that sera from dogs suffering juvenile generalized demodicosis, with and without secondary pyoderma, reacted with $10 \mathrm{kDa}$ and 55/72 kDa Demodex antigens, respectively, by Western blot; however, sera from healthy dogs also reacted with bands of 55 and $72 \mathrm{kDa}$, suggesting that both dogs with generalized demodicosis and healthy dogs develop a humoral response against different proteins of D. canis (RAVERA et al., 2015).

Atopic dermatitis (AD) is one of the most common allergic skin diseases of dogs. This entity has been defined as a genetically predisposed (MAZRIER et al., 2016), inflammatory and pruritic allergic skin disease with typical clinical features (OLIVRY et al., 2001). The variation in clinical presentations, due to genetic factors, extent of the lesions, stage of the disease, secondary infections, as well as resemblance to other non-atopic related skin diseases, can complicate a diagnosis of canine AD (HENSEL et al., 2015). The exact prevalence of AD is not known, but there are reports suggesting that approximately $10 \%$ of the canine populations are affected worldwide (SCOTT, 2001). The canine epicutaneous exposure to different allergens may play an important role during both the sensitization and the perpetuation of AD (PUCHEU-HASTON et al., 2008), and is often associated with the presence of isotype $\mathrm{E}$ immunoglobulin (IgE) to environmental allergens (HILLIER; GRIFFIN, 2001).

Dermatophagoides pteronyssinus, D. farinae and Blomia tropicalis are the most prevalent house dust mites in tropical and subtropical climates and are considered the major sources of house dust allergens (ARLIAN et al., 1992; FERNANDEZCALDAS et al., 1993). Previous studies reported a high frequency of $\operatorname{IgE}$ antibodies to $D$. pteronyssinus and $D$. farinae in dogs with $\mathrm{AD}$, but also in dogs with no skin disease (LIAN; HALLIWELL, 1998; ARLIAN; MORGAN, 2000). Also, mite-sensitized dogs with AD show cosensitization to storage mites, such as Acarus siro, Tyrophagus putrescentiae and Lepidoglyphus destructor (SARIDOMICHELAKIS et al., 2008). Despite $D$. pteronyssinus and $D$. farinae mite allergens being found in the environments in our region, southeastern of Brazil (reviewed by SEGUNDO et al., 2009), D. pteronyssinus was found as the most prevalent house dust mite identified in the fauna in northeastern Brazil (Salvador, BA) (SERRAVALLE; MEDEIROS, 1999) and D. pteronyssinus and B. tropicalis in southeastern Brazil (São Paulo, SP) (JORGE NETO; CROCCE; BAGGIO, 1980). Both in vivo and in vitro studies have demonstrated that there is cross-reactivity and cross-sensitization between antigens of Sarcoptes scabiei and D. farinae and D. pteronyssinus (FALK; BOLLE, 1980a, 1980b; PRÉLAUD; GUAGUÉRE, 1995). However, little is known about the cross-sensitization between $D$. canis and house dust mite allergens.

At first, in the present study we aimed to investigate the more prevalent parasitic skin disease in the southeastern region of Brazil; and the Demodex was the most prevalent mite detected in skin diseased dogs in the region. Generalized demodicosis leads to a T-cell immunosuppression and there are little studies focusing on humoral immune response specific to the disease. Dogs suffering juvenile generalized demodicosis present serum IgG that recognize Demodex antigens (RAVERA et al., 2015) and serological IgA was enhanced in Pit bull terrier-type dogs (SOUZA et al., 2018). Related to $A D$, one of the most common allergic canine skin diseases, diseased dogs presented IgE-mediated sensitization to allergens from Dermatophagoides mites (MASUDA et al., 1999). Thus, we decided to investigate IgE and IgG serum antibody responses to Dermatophagoides mites in $\mathrm{AD}$ and demodicosis dogs and verify if 
there is antibody cross-reactivity between demodex mites and $\mathrm{Dp}$ antigens detected by canine antibodies. For this purpose, the IgG serum antibody response to the house-dust mite $D$. pteronyssinus and $D$. farinae, and also $\operatorname{IgE}$ to $D$. pteronyssinus were evaluated in serum samples collected from new groups of dogs with $\mathrm{AD}$ or demodicosis. Also, the major IgE-binding $D$. pteronyssinus proteins that are recognized by sera from dogs with demodicosis were evaluated.

\section{MATERIALS AND METHODS}

\section{Epidemiological study}

At first an epidemiological investigation was conducted by analyzing clinical files of 2,599 dogs that were admitted at the Veterinary Hospital, Federal University of Uberlândia, Brazil, over a period of 1 year, between January and December 2008 , in order to identify the most frequent mites inducing skin diseases in dogs in this southeastern region of the country. Epidemiologic data included age, sex, breed and results of skin scrapings.

\section{Animals and serum samples}

After identifying that the genus Demodex spp. was the most frequent mite provoking skin disease in dogs by epidemiological investigation, serum samples were obtained from new group of animals, 19 dogs of both genders and different ages and breeds, presenting symptoms of skin diseases and diagnosed as demodicosis. These samples came from the Veterinary Hospital, Federal University of Uberlândia, Brazil, private veterinary clinics of the city, and the Zoonosis Control Center of Uberlândia, collected between January and December 2009. Inclusion criteria were symptoms of skin disease and the detection of $D$. canis in skin scrapings and/or hair plucking samples from skin lesions. The samples were collected over a period of 1 year. A second group consisted of serum samples obtained from 28 dogs with $\mathrm{AD}$ according to previously published criteria (HENSEL et al., 2015), that were attended at the Veterinary Hospital, Federal University of Uberlândia, Brazil, over a period of 1 year. Inclusion criteria were the presence of pruritic skin lesions associated with a positive intradermal skin test (IDST) to Dermatophagoides spp. extracts (KEPPEL et al., 2008), and these sera were used as positive controls in immunoassays. A third group consisted of clinically healthy $(n=25)$ dogs with no previous clinical history or sign of skin disease and a negative IDST to Dermatophagoides spp. extracts and, also Demodex upon microscopic examination of parasitological skin scraping samples. These animals were admitted to the Veterinary Hospital, Federal University of Uberlândia, Brazil, for regular health-check or vaccination was included in the study as negative controls, after obtaining permission from the owners. This group was divided in animals more than $12 \mathrm{mo}$ and less than $12 \mathrm{mo}$, to indicate higher and less probability, respectively to be exposed to the Dermatophagoides allergens.

Blood samples were collected by cephalic or jugular venipuncture, and sera were obtained after centrifugation at $300 \mathrm{~g}$ for $10 \mathrm{~min}$ and stored at $-20^{\circ}$ $\mathrm{C}$ until serological assays. All procedures including blood sample collection, skin scraping and intradermal testing were carried out in accordance with the recommendations of International Guiding Principles for Biomedical Research Involving Animals.

\section{Skin scrapings}

Skin samples were taken from five areas of lesions by scraping with a scalpel until capillary bleeding was visible. The scraped materials were placed on glass slides with a drop of $10 \%$ potassium hydroxide $(\mathrm{KOH})$ solution, and coverslips were placed on top of each (RODRIGUEZ-VIVAS et al., 2003). The slides were examined under light microscopy using a $10 \mathrm{x}$ objective to investigate the presence of mites in any developmental stage that were considered as positive sample (RODRIGUEZVIVAS et al., 2003).

\section{Dermatophagoides pteronyssinus and D. farinae extracts}

Dermatophagoides pteronyssinus (Dp) or D. farinae (Df) crude extracts (Ext-Dp or Ext-Df) was obtained from mite bodies and feces (cultures containing mites kindly provided by Dr. Federico Montealegre, Ponce School of Medicine, Puerto Rico) as described elsewhere (MONTEALEGRE et al., 2002; PEREIRA et al., 2005). Briefly, mite and feces powder was triturated in liquid nitrogen for mite disruption and allergens were extracted overnight at $4{ }^{\circ} \mathrm{C}$ in $5 \mathrm{mmol} / \mathrm{L}$ borate-buffered saline ( $\mathrm{pH} 8.0)$ containing protease inhibitors $(50$ $\mu \mathrm{g} / \mathrm{mL}$ leupeptin, $1.6 \mathrm{mmol} / \mathrm{L}$ phenylmethylsulfonyl fluoride [PMSF], $1 \mathrm{mmol} / \mathrm{L}$ benzamidin, and 10 $\mu \mathrm{g} / \mathrm{mL}$ aprotinin; all reagents from Sigma Chemical Co. Saint Louis, Missouri). After centrifugation $\left(30,000 \mathrm{~g}\right.$ for $45 \mathrm{~min}$ at $\left.4{ }^{\circ} \mathrm{C}\right)$, the supernatant was dialyzed (Amicon, Ym-10, W.R. Grace \& Co., Beverly, Massachusetts) against $0.01 \mathrm{mmol} / \mathrm{L}$ phosphate-buffered saline (PBS, pH 7.2) and the protein concentration was determined (LOWRY et al., 1951). Mite extract aliquots were stored at -20 ${ }^{\circ} \mathrm{C}$ until being used in immunoassays. 
Enzyme-linked immunosorbent assay (ELISA) for measuring IgE antibodies to $D$. pteronyssinus

Levels of serum $\operatorname{IgE}$ antibodies to $\mathrm{Dp}$ antigens were measured by ELISA as described elsewhere (ALMEIDA et al., 2006), with some modifications. High affinity microtiter plates (Corning Laboratories Inc., New York, NY, USA) were coated overnight at $4{ }^{\circ} \mathrm{C}$ with $20 \mu \mathrm{g} / \mathrm{mL}$ of Ext-Dp diluted in $0.06 \mathrm{mmol} / \mathrm{L}$ carbonate buffer $(\mathrm{pH}$ 9.6). The plates were washed three times with phosphate-buffered saline PBS containing $0.05 \%$ Tween 20 (PBS-T) and blocked with PBS-T containing $1 \%$ bovine serum albumin (BSA) for $1 \mathrm{hr}$ at room temperature. After washes, plates were incubated with dog serum samples diluted 1:2 in PBS-T-BSA for $2 \mathrm{hr}$ at $37{ }^{\circ} \mathrm{C}$, washed again and then with mouse monoclonal IgG1 anti-canine IgE (Serotec Inc., Raleigh, North Carolina) diluted 1:500 in PBS-T-BSA for $1 \mathrm{hr}$ at $37{ }^{\circ} \mathrm{C}$. Next, the peroxidase-labeled goat anti-mouse $\operatorname{IgG}$ conjugate (Sigma) diluted 1:1,000 in PBS-T-BSA was added and incubated for $1 \mathrm{hr}$ at $37{ }^{\circ} \mathrm{C}$. The assay was developed by adding $0.01 \mathrm{mmol} / \mathrm{L} 2,2^{\prime}$-azino-bis-3ethyl-benzthiazoline sulfonic acid (ABTS; Sigma) in $0.07 \mathrm{mmol} / \mathrm{L}$ citrate-phosphate buffer $(\mathrm{pH} 4.2)$ and $0.03 \% \mathrm{H}_{2} \mathrm{O}_{2}$. Optical density (OD) values were determined in a plate reader (Titertek Multiskan, Flow Laboratories, McLean, Virginia) at $405 \mathrm{~nm}$. Antibody levels were arbitrarily expressed as ELISA index (EI) according to the formula: EI = sample OD/cut off, where cut off was established as mean OD of negative control sera plus 3 standard deviations (SD) (SILVA et al., 2002). It was used 3SD plus the mean OD of negative control sera to make the analyzes more rigid. EI values $>1.2$ were considered positive for excluding borderline reactivity values close to $\mathrm{EI}=1.0$.

ELISAs for measuring IgG antibodies to D. pteronyssinus or $D$. farinae and $D$. pteronyssinus IgG avidity

Levels of specific IgG antibodies to Dp or Df antigens were measured by ELISA as above described, with minor modifications. Briefly, high affinity microtiter plates were coated with $20 \mu \mathrm{g} / \mathrm{mL}$ of Ext-Dp, blocked with PBS-T-BSA and then incubated with dog serum samples diluted 1:25 in PBS-T-BSA for $1 \mathrm{hr}$ at $37{ }^{\circ} \mathrm{C}$. After washing, the peroxidase-labeled goat anti-dog IgG conjugate (Sigma-Aldrich, St. Louis, MO, USA) diluted 1:5,000 in PBS-T-BSA was added and incubated for $1 \mathrm{hr}$ at $37^{\circ} \mathrm{C}$. The assay was developed by adding ABTS and $0.03 \% \mathrm{H}_{2} \mathrm{O}_{2}$ and results were expressed as described for ELISA-IgE to Dp.
The avidity of Dp -specific IgG antibodies was determined as previously described (MARCOLINO et al., 2000), with some modifications. Briefly, microtiter plates previously coated with Ext-Dp were washed 3 times with PBST. Serum samples diluted 1:25 were added in duplicate on separate plates. After incubation for 45 min at $37{ }^{\circ} \mathrm{C}$, the plates were subjected to differential washing as follows: 1 plate was washed with $6 \mathrm{M}$ urea solution in PBS for $5 \mathrm{~min}$, while the other plate was washed only with PBS-T for 5 min. Furthermore, both plates were washed twice with PBS-T for $5 \mathrm{~min}$. The residual antigen-bound IgG was detected with peroxidase-labeled goat anti-dog IgG conjugate (Sigma) diluted 1:5,000 in PBS-TBSA and incubated for $45 \mathrm{~min}$ at $37^{\circ} \mathrm{C}$. After three washes with PBS-T, the reaction was revealed with ABTS and $0.03 \% \mathrm{H}_{2} \mathrm{O}_{2}$. The avidity index (AI) was calculated as the ratio between the absorbance (Abs) obtained for the plate washed with urea $(\mathrm{U}+)$ and the plate without urea (U-) and is expressed as a percentage: $\mathrm{AI} \operatorname{Abs}\left(\mathrm{U}^{+}\right) / \mathrm{Abs}\left(\mathrm{U}_{-}\right) \mathrm{x} 100$.

\section{Immunoblot}

To identify the IgE-reactive Dp antigens, 10 sera from dogs with demodicosis and 5 sera from dogs with $\mathrm{AD}$ were analyzed in immunoblot as previously described (PEREIRA et al., 2005). ExtDp $(20 \mu \mathrm{g})$ was electrophoresed on $12 \%$ sodium dodecyl sulfate polyacrylamide gel (SDS-PAGE) in a mini-gel system (Hoefer Pharmacia Biotech Inc., San Francisco, California), under non-reducing conditions (without 2-mercaptoethanol) (LAEMMLI, 1970) in parallel with standard molecular markers (Sigma). Then, previously separated Ext-Dp was electrotransferred onto a nitrocellulose membrane (Amersham, Milan, Italy) as described elsewhere (TOWBIN; STSEHELIN; GORDON, 1979). Membrane strips were blocked with 5\% skimmed milk (SM) in PBS-T and incubated with dog serum samples diluted at 1:4 in PBS-T plus $1 \%$ SM overnight at $4{ }^{\circ} \mathrm{C}$. Negative control sera were also included. After washing six times with PBS-T, mouse monoclonal IgG1 anticanine IgE (Serotec Inc.) diluted 1:250 in PBS-T plus $1 \%$ SM was added and incubated for $4 \mathrm{hr}$ at room temperature. After new washes, strips were incubated with the peroxidase-labeled goat antimouse IgG (Sigma) diluted 1:1,000 in PBS-T plus $1 \% \mathrm{SM}$ for $2 \mathrm{hr}$ at room temperature. The reaction was visualized using 3, 3'-diaminobenzidine tablets (Sigma) and hydrogen peroxide. 


\section{Statistical analysis}

Statistical analysis was performed using GraphPad Prism, v. 8.0 (GraphPad Software, San Diego, California). Antibody levels were compared between two groups with Student's $t$ test, for parametric data, or by Mann-Whitney test, for nonparametric data, and among more groups with OneWay ANOVA with Bonferroni's multiple comparison post-test. Positive rates were compared by the chi-square $\left(\chi^{2}\right)$ test. Values of $P<0.05$ were considered statistically significant.

\section{RESULTS}

\section{Epidemiological study}

From 2,599 clinical files analyzed, 111 dogs

were clinically suspected of having skin diseases.
As demonstrated in Table 1, from 111 skin diseased dogs, $42(37.8 \%)$ were male and $69(62.2 \%)$ were female $\left(\chi^{2}=12.2, P=0.0005\right)$, and $80(72.1 \%)$ were pure breed dogs compared to 31 (27.9\%) mixed breed $\operatorname{dogs}\left(\chi^{2}=41.5, P<0.0001\right)$. Results of skin scrapings demonstrated that 29 dogs were positive for mange mites $(26.1 \%)$ and 82 were positive for other skin diseases $(73.9 \%)\left(\chi^{2}=48.7, P<0.0001\right)$. Demodectic mange was diagnosed in $23(20.7 \%)$ dogs with skin disease and was more frequent than sarcoptic mange, which was seen in only $6(5.4 \%)$ $\operatorname{dogs}\left(\chi^{2}=10.2, P=0.0014\right)$ (Table 1). Also, demodectic mange was more prevalent in pure than mixed breed $\operatorname{dogs}\left(\chi^{2}=8.7, P=0.0032\right)($ Table 1$)$.

Table 1. Epidemiological data of 111 dogs with skin disease admitted at the Veterinary Hospital, Federal University of Uberlândia, Brazil.

\begin{tabular}{|c|c|c|c|c|c|c|c|c|}
\hline \multirow{2}{*}{ Skin disease } & \multicolumn{2}{|c|}{ Age (mo) } & \multicolumn{2}{|c|}{ Breed $^{1}$} & \multicolumn{2}{|l|}{ Sex } & \multicolumn{2}{|l|}{ Total } \\
\hline & $<12$ & $>12$ & Pure & Mixed & Male & Female & $\begin{array}{l}\text { Positive } \\
\text { (n) }\end{array}$ & $\begin{array}{l}\text { Prevalence } \\
(\%)\end{array}$ \\
\hline Demodectic mange & 14 & 9 & $17 *$ & $6 \dagger$ & 11 & 12 & 23 & $20.7^{*}$ \\
\hline Sarcoptic mange & 3 & 3 & 4 & 2 & 1 & 5 & 6 & $5.4 \dagger$ \\
\hline Other skin diseases & $33 *$ & $49 \dagger$ & $59 *$ & $23 \dagger$ & $30 *$ & $52 \dagger$ & 82 & $73.9 \ddagger$ \\
\hline Total & 50 & 61 & $80 *$ & $31 \dagger$ & $42 *$ & $69 \dagger$ & 111 & 100 \\
\hline
\end{tabular}

${ }^{1}$ The purebreds were German Shepherd, Rottweiler, Labrador, Brazilian Fila, or Beagle; $*, \dagger, \ddagger$ Different symbols indicate significant differences as determined by the $\chi 2$ test with Yates correction $(P<0.05)$.

\section{IgG antibodies to $D$. pteronyssinus and $D$. farinae in dog sera}

In the next step, we investigated if sera from dogs with demodicosis could also react with $D$. pteronyssinus antigens, testing in parallel the sera from dogs with $\mathrm{AD}$ (positive controls) and with no dermatitis (negative controls). The majority 18 (94\%) from 19 dogs with demodicois was $>12$ mo old, $10(52.6 \%)$ were male and $15(78.9 \%)$ were pure breed, predominating in dogs of German Shepherd breed. It was observed that dogs with $\mathrm{AD}$ or demodicosis presented high seropositivity rates (> 90\%) and similar levels of circulating IgG antibodies to Dp (Figure 1A). On the other hand, dogs with no sign of dermatitis also had Dp-specific IgG antibodies, but with significantly lower IgG levels and seropositivity rates than dogs with demodicosis or $\mathrm{AD}(P=0.0374$ and $P=0.0222)$. We also measured the Df-specific IgG antibodies in sera from demodicosis and healthy dogs, and all of demodectic dogs presented positivity to Df, despite in low levels (Figure 1D) and dogs with no sign of dermatitis also had Df-specific IgG antibodies (Figure 1D).

As the majority of dogs (94\%) with demodicosis were $>12$ mo old, we decided to analyze the Dp and Df-specific IgG detection in dogs with no dermatitis (negative controls) in relation to the age of these animals. We observed that higher IgG levels as well as seropositivity were detected in dogs $>12$ mo old $(P=0.0001)$ (Figure $1 \mathrm{~B}$ and $1 \mathrm{E})$. As the IgG levels in demodectic dogs were higher when using Dp than Df antigens, and also based in the literature that D. pteronyssinus is highly prevalent in our region, the posterior studies were performed with Dp only.

Next, we analyzed the Dp-specific IgG avidity of sera from dogs with demodicosis and dogs with no dermatitis, and detected a higher IgG avidity index in sera from dogs with demodicosis $(P$ $=0.0217$ in relation to dogs with no dermatitis $>12$ mo old, and $P=0.0001$ in relation to dogs with no dermatitis $<12$ mo old) (Figure 1C). 
A
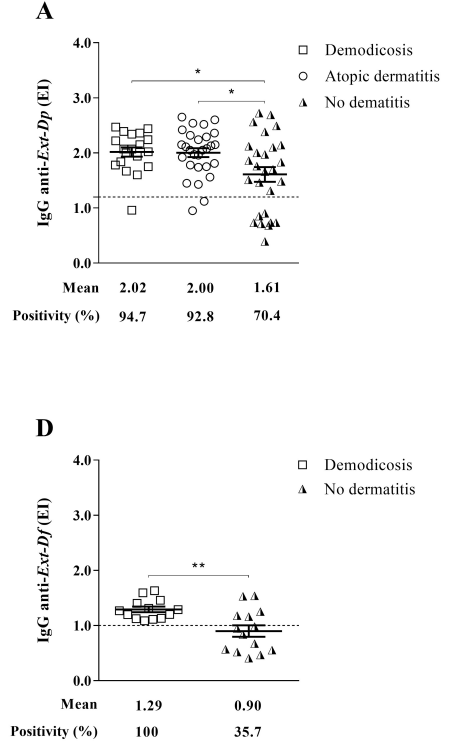

B
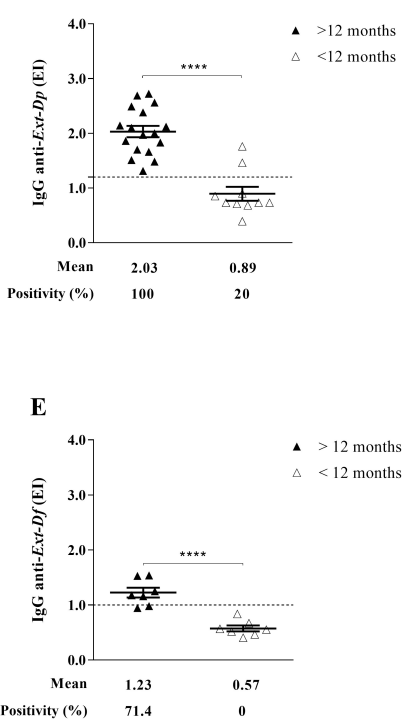

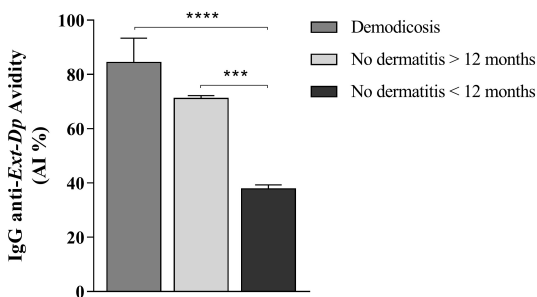

Figure 1. Levels of IgG to Dermatophagoides pteronyssinus and Dermatophagoides farinae extracts determined by ELISA in serum samples from dogs.

The specific IgG levels to D. pteronyssinus were measured in serum samples from dogs with atopic dermatitis $(\mathrm{n}=28)$, demodicosis $(n=19)$, and healthy dogs $(n=25)(\mathbf{A})$. Levels of $\operatorname{IgG}$ in $<12$ mo and $>12$ mo old healthy dogs $(\mathbf{B})$. Percentage of IgG anti-Ext-Dp avidity in serum samples of demodicosis and healthy dogs (C). Levels of IgG to D. farinae extract determined by ELISA in serum samples from dogs with demodicosis $(\mathrm{n}=13)(\mathbf{D})$, and healthy dogs $(\mathrm{n}=14)(\mathbf{E})$. Data are reported as ELISA index (EI) or avidity index (AI) expressed as a percentage. The horizontal bars in the graphs indicate the mean value obtained for each group. The dashed horizontal lines indicate the cut-off of the assay $(\mathrm{EI}=1.2)$. Statistical significance was determined using the One-way ANOVA with Bonferroni's multiple comparison test (A and C) or the Student's $t$ test (B, D and E). ${ }^{*} P<0.05$.

\section{IgE antibodies to $D$. pteronyssinus in dog sera}

To confirm the sensitization of dogs with $\mathrm{AD}$ to $\mathrm{Dp}$ allergens and investigate if dogs with demodicosis were also sensitized to the dust mite, we analyzed serum IgE levels to Dp in both dog groups in addition to the group with no dermatitis (negative control). Dp-specific IgE levels were significantly higher in dogs with AD compared with demodicosis $(P=0.0457)$ and with no sign of dermatitis $(P=0.0001)$ (Figure 2A). However, seropositivity rates for Dp-specific IgE in dogs with $\mathrm{AD}(85.7 \%)$ and demodicosis $(63.2 \%)$ were not significantly different, but both groups showed higher specific IgE seropositivity than healthy dogs $(32.0 \%)\left(\chi^{2}=15.9, P<0.0001\right.$ and $\chi^{2}=4.2, P=$ 0.0398 , respectively). Interestingly, dogs with no dermatitis and age $<12$ mo presented lower levels and seropositivity of Dp-specific IgE antibodies compared to those with $>12$ mo old $(P=0.0001)$ (Figure 2B). 

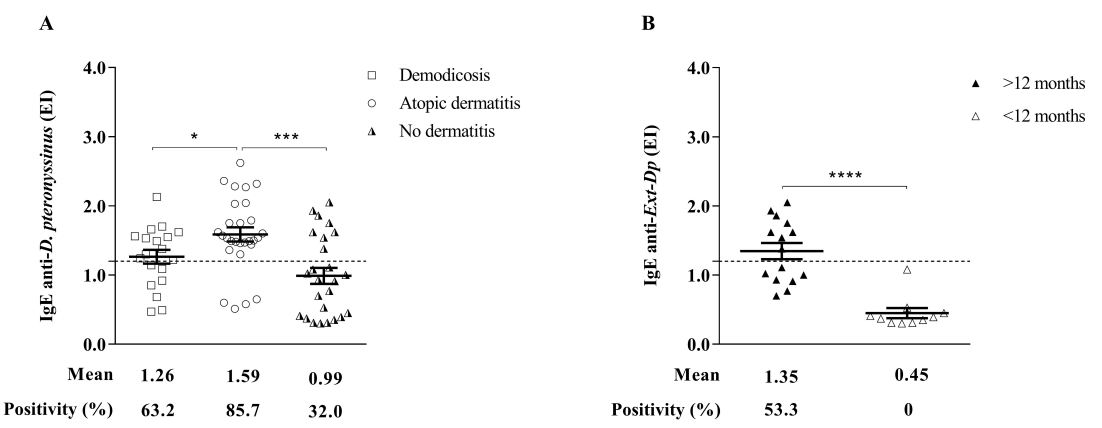

Figure 2. Levels of IgE to Dermatophagoides pteronyssinus extract determined by ELISA.

The IgE levels were measured in serum samples from dogs with atopic dermatitis $(n=28)$, demodicosis $(n=19)$, and healthy dogs $(n=25)(\mathbf{A})$. Levels of IgE in $<12$ mo and $>12$ mo old healthy dogs $(\mathbf{B})$. Data are reported as ELISA index (EI). The horizontal bars in the graphs indicate the mean value obtained for each group. The dashed horizontal lines indicate the cut-off of the assay $(\mathrm{EI}=1.2)$. Statistical significance was determined using the One-way ANOVA with Bonferroni's multiple comparison test (A) or the Mann-Whitney test (B). ${ }^{*} P<0.05$.

Profile of $D$. pteronyssinus protein/peptide bands detected by IgE antibody from sera of dogs with AD or demodicosis using immunoblot assay

To investigate probable antigenic markers in the Ext-Dp that could be differentially or concomitantly recognized by $\operatorname{IgE}$ antibodies in sera of dogs with $\mathrm{AD}$ and demodicosis, Ext-Dp-blotted membranes were probed with sera from the three dog groups. Sera from both dogs with demodicosis (Figure 3A) and AD (Figure 3B) recognized 3 major protein/peptide bands with relative molecular masses of approximately 40, 72, and $116 \mathrm{kDa}$, with a stronger reactivity to the 72 and $116 \mathrm{kDa}$ bands. Additionally, serum samples from healthy dogs with no dermatitis recognized predominantly the band of $72 \mathrm{kDa}$, despite the weak reactivity with minor bands (Figure 3C, lines 12, 13, and 14). As expected, sera from healthy dogs $<12$ mo old presented no $\mathrm{IgE}$ reactivity to Ext-Dp (Figure 3C, lines 15 and 16).

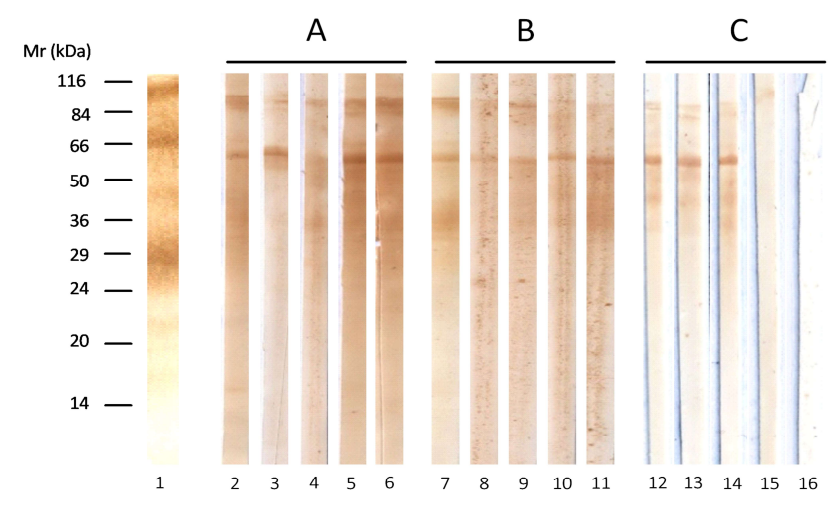

Figure 3. Immunoblot of Dermatophagoides pteronyssinus (Dp) extract probed with canine sera.

Dp extract $(20 \mu \mathrm{g}$ protein) was resolved on $12 \%$ SDS-PAGE under non-reducing conditions, proteins were transferred to nitrocellulose membrane and strips were probed with sera from dogs with demodicosis (A), atopic dermatitis (B) or healthy dogs (C). Crude Dp extract (line1). Representative serum samples from dogs with demodicosis (lines 2, 3, 4, 5, 6), atopic dermatitis (lines $7,8,9,10,11$ ) and from healthy dogs $>12$ mo (lines 12, 13,14) and $<12$ mo (lines 15, 16). Monoclonal mouse anti-canine IgE and afterwards peroxidase-labeled goat anti-mouse IgG conjugate were used to detect canine $\operatorname{IgE}$ reactivity to Dp extracts. Molecular mass $(\mathrm{kDa})$ standards are indicated on the left. 


\section{DISCUSSION}

There is limited information about the prevalence and immune response to the mange-mite $D$. canis worldwide. In the present investigation, $D$. canis $(20.7 \%)$ was more prevalent than S. scabiei $(5.4 \%)$ in this region of southeastern Brazil in an epidemiologic analysis. These findings are in accordance with another study performed in Brazil, showing that in the city of Mossoro, northeastern region of Brazil, $13.9 \%$ of 503 dogs examined presented $D$. canis mites in cutaneous smears and were the more prevalent mites found (ROCHA et al., 2008). In another study, in the city of Lages, southern Brazil, the prevalence of mange mites in 714 dogs examined was $7.7 \%$, which was much lower than our findings (26.1\%), but showing similar frequency of $D$. canis and S. scabiei $(48.28 \%)$ (BELLATO et al., 2003). Our investigation was also in accordance with previous studies performed in Mexico, where $D$. canis was the most frequent $(23 \%)$ mange mite infestation in stray dogs (RODRIGUEZ-VIVAS et al., 2003). In a northern area of Taiwan in an analysis of 1,013 dogs, $73(7.2 \%)$ presented D. canis infection (TSAI et al., 2011). Interestingly, in our investigation, the epidemiological study showed that demodicosis was more frequent in pure breed dogs. Our data are in accordance with previous studies that showed that from 16 demodectic dogs $14(87.5 \%)$ were pure breed (OLIVEIRA; LARSSON; DE CAMARGO, 2015).

House dust mites are found in homes worldwide and dogs reside in many homes in geographical areas and climates where these mites are prevalent (MASUDA et al., 1999). Previous in vivo and in vitro investigations have shown crossreactivity and cross-sensitization between antigens of $S$. scabiei and house dust mites as D. farinae and D. pteronyssinus (FALK; BOLLE, 1980a, 1980b; ARLIAN; VYSZENSKI-MOHER; GILMORE, 1988, 1991; PRÉLAUD; GUAGUÉRE, 1995). Dogs produce both IgG and IgE to house dust mites and IgE-mediated sensitization to allergens from these mites is often manifested as AD (MASUDA et al., 1999).

In the present study, dogs with $\mathrm{AD}$ or demodicosis and ones presenting no signs of dermatitis, exhibited circulating $\operatorname{IgG}$ and $\operatorname{IgE}$ antibodies to $D$. pteronyssinus. According to the high prevalence of house dust mites in tropical climates (ARLIAN et al., 1992; FERNANDEZCALDAS et al., 1993), including Brazil (TERRA et al., 2004), the data obtained in this study reinforces that $D$. pteronyssinus presents a high prevalence in our region and the mites are sensitizing dogs. In other regions of the world, intradermal test reactions in atopic dogs to $D$. farinae are more frequent than to D. pteronyssinus (MASUDA et al., 2000; BENSIGNOR; CARLOTTI, 2002; SZCZEPANIK; WILKOLEK; TASZKUN, 2005) and despite the rarity of $D$. farinae in the U.K. the sensitization to $D$. farinae in $\mathrm{AD}$ dogs is more frequent than to $D$. pteronyssinus (STURE et al., 1995). It was observed exposure to $D$. farinae antigens by detection of $\mathrm{IgG}$ specific to Df in sera from demodectic and healthy dogs, however in low antibody levels. Interestingly, in our study dogs with $\mathrm{AD}$ or demodicosis or even healthy dogs presented high exposure to $D$. pteronyssinus and, high sensitization to $D$. pteronyssinus antigens. It is in accordance with the high prevalence of D. pteronyssinus in different regions of Brazil (JORGE NETO; CROCCE; BAGGIO, 1980; SERRAVALLE; MEDEIROS, 1999;).

$\operatorname{IgE}$ antibody is commonly associated with sensitization to environmental allergens (HILLIER; GRIFFIN, 2001) and the role of $\operatorname{IgG}$ in the pathogenesis of $\mathrm{AD}$ is not completely elucidated (PUCHEU-HASTON et al., 2015). We observed that high levels of IgG antibodies to $D$. pteronyssinus were detected in sera from both dogs with $\mathrm{AD}$ and demodicosis. On the other hand, serum samples from healthy dogs with no history of skin disease also exhibited D. pteronyssinus-specific IgG antibodies, despite at lower levels than those observed in dogs with $\mathrm{AD}$ and demodicosis. It is noteworthy, however, that $70 \%$ of these positive sera were from dogs aged $>12 \mathrm{mo}$, and all of these animals presented mean of ELISA index of 2.03, similar to those of $\mathrm{AD}$ and demodicosis dogs. The majority of dogs with demodicosis in our investigation were $>12$ mo age. Thus, these data suggest that the demodicosis and healthy dogs $>12$ mo were previously exposed to $D$. pteronyssinus antigens.

In the next step, we measured the avidity of IgG to Ext-Dp in sera from dogs with demodicosis and healthy dogs $>12$ mo old. Previous studies showed that low and high IgG avidity reflects recent and chronic infection, respectively (MARCOLINO et al., 2000). In the present work, the higher Dpspecific IgG avidity detected in the demodicosis group compared with healthy dogs could indicate that dogs with demodicosis were exposed to $D$. pteronyssinus antigens earlier than healthy dogs, mainly dogs with $<12$ mo reflecting on increased affinity and maturation of specific antibodies due to longer time to Dp exposition. Regarding IgE levels to D. pteronyssinus, higher specific IgE levels were 
found in dogs with $\mathrm{AD}$ when compared with those with demodicosis or healthy. Interestingly, healthy dogs with no history of skin disease that exhibited Dp-specific IgE antibodies (32\%) were all $>12$ mo of age. These data suggest that Dp-specific IgE rather than $\operatorname{IgG}$ levels may better discriminate dogs with $\mathrm{AD}$ from healthy dogs or even those with demodicosis. Accordingly, previous studies showed that there is a high frequency of $\operatorname{IgE}$ antibody to $D$. farinae and D. pteronyssinus allergens in both atopic and normal dogs (LIAN; HALLIWELL, 1998; ROQUE et al. 2011; LAUBER et al., 2012). These data indicate that IgG and IgE levels to house dust mite allergens must be evaluated with careful in the diagnosis of $\mathrm{AD}$ because dogs can be mitesensitized, but do not show any clinical sign of AD. Similarly, another study demonstrated that mitesensitized dogs presented high concentration of serum $D$. farinae- and D. pteronyssinus -specific IgE and no clinical signs of AD (EGLI et al., 2002). Likewise, our study showed that many randomsource dogs without scabies, demodicosis or signs of $\mathrm{AD}$ or other visible skin lesions might already have sensitizing levels of circulating $\operatorname{IgE}$ antibody to house dust mite allergens.

$\operatorname{IgE}$ antibodies in the serum of dust mitesensitized patients with no history of scabies bind to multiple S. scabiei protein/peptide components separated by SDS-PAGE (ARLIAN; VYSZENSKIMOHER; GILMORE, 1988). In the present study, D. pteronyssinus protein/peptide components separated by SDS-PAGE were recognized by IgE antibodies in sera of dogs with $\mathrm{AD}$, demodicosis and healthy ones. Sera from dogs with $\mathrm{AD}$ and demodicosis predominantly recognized the protein/peptide bands of 40, 72 and $116 \mathrm{kDa}$ from Ext-Dp. The reactivity of the 72 and $116 \mathrm{kDa}$ bands was more evident, indicating that these protein components seem to be immunodominant antigens that induce a strong homologous and/or heterologous IgE antibody immune response. However, sera from healthy dogs recognized mainly the $72 \mathrm{kDa}$ protein/peptide band. Recently, it was demonstrated that sera from some dogs with demodicosis recognized protein/bands in the $D$. farinae extract. One from three groups of pooled sera obtained from dogs with generalized demodicosis without concurrent secondary pyoderma detected a band of $72 \mathrm{kDa}$ in the $D$. farinae extract and 1 from 4 groups of pooled sera from dogs with generalized demodicosis with secondary pyoderma detected a band around $10 \mathrm{kDa}$ in this extract (RAVERA et al., 2015). In accordance with our study, in atopic dogs the major allergens of $D$. farinae and $D$. pteronyssinus detected by $\operatorname{IgE}$ antibodies were at $97-98 \mathrm{kDa}, 103-$ $104 \mathrm{kDa}$ and 134-139 $\mathrm{kDa}$ on both reducing and non-reducing blots and 84-85 kDa, 65-69 kDa and 44-45 $\mathrm{kDa}$ on reducing blots (NUTTALL; LAMB; HILL, 2001). Additionally, IgE from sera of atopic dogs recognized bands of 13.5, 23.5, 32.5, 47.5, 70 and $210-220 \mathrm{kDa}$ more frequently in $D$. pteronyssinus extract by one-dimensional SDSPAGE (MARTINS et al., 2015).

Using a whole body, D. canis crude protein extract, Ravera et al. (2015) observed that sera from dogs with generalized demodicosis without secondary pyoderma detected bands towards $10 \mathrm{kDa}$ and 55 to $72 \mathrm{kDa}$, whereas sera from generalized demodicosis with secondary pyoderma detected bands towards $10 \mathrm{kDa}$. Thus the $72 \mathrm{kDa}$ band in $D$. canis and D. farinae or D. pteronyssinus (the latter observed in our study) extract detected by sera from dogs with demodicosis could be a shared antigen between these 3 mites. These data reinforce the careful necessary to diagnose the canine skin disease, because Demodex mites could induce crossreactivity response that could misdiagnosis $\mathrm{AD}$. Thus, complementary approaches are essential to improve the diagnosis, such as, ruling out of other skin conditions with clinical signs that can resemble, or overlap with canine $\mathrm{AD}$, such as ectoparasitic skin diseases; detailed interpretation of the historical and clinical features of the condition, afterwards assessment of skin reactivity by intra dermal testing or serologic detection of specific-IgE in serum samples (HENSEL et al., 2015) or specific peptide/antigen from house dust mites recognized by $\operatorname{IgE}$.

In conclusion, our investigation demonstrated that dogs with demodicosis present antibodies IgG that recognize D. pteronyssinus and $D$. farinae and, $\mathrm{IgE}$ that recognize $D$. pteronyssinus antigens, meaning that the animals have been previously exposed/sensitized to house dust mites; however, the $72 \mathrm{kDa}$ antigen could to be an immunodominant antigen that induces a strong homologous and $\mathrm{Dp}$ heterologous $\mathrm{IgE}$ antibody response. Therefore, the continuous exposure to house dust mite allergens and consequent sensitization of dogs with more age associated with a possible IgE antibody cross-reactivity between $D$. pteronyssinus and D. canis might lead to symptom exacerbation of skin lesions in dogs with demodicosis.

\section{ACKNOWLEDGMENTS}

This work was supported by Conselho Nacional de Pesquisa Científica e Tecnológica 
(CNPq) and Fundação de Amparo à Pesquisa do Estado de Minas Gerais (FAPEMIG). In addition, this study was financed in part by the Coordenação de Aperfeiçoamento de Pessoal de Nível Superior Brazil (CAPES) - Finance Code 001. JRM and NMS are research fellows from $\mathrm{CNPq}$.

RESUMO: Demodicose canina é uma doença inflamatória comum da pele causada por ácaros do gênero Demodex. Ácaros da poeira doméstica como Dermatophagoides spp. desempenham papel importante na patogênese da dermatite atópica canina (DA). O objetivo desse trabalho experimental foi investigar se cães com demodicose poderiam ser previamente expostos/sensibilizados com antígenos de ácaros da poeira doméstica. A princípio, investigou-se a prevalência de demodicose em uma região sudeste do Brasil, analisando-se prontuários clínicos de cães admitidos em um Hospital Veterinário. Posteriormente, as respostas de IgG a Dermatophagoides pteronyssinus (Dp) e D. farinae (Df) e IgE a D. pteronyssinus (Dp) foram avaliadas em dois grupos, DA ou demodicose. Também foram avaliadas as principais proteínas Dp reconhecidas por anticorpo IgE presente em soros de cães com demodicose e DA. Um total de 2.599 prontuários clínicos foram analisados para identificar as principais doenças parasitárias da pele em cães dessa região, considerando a idade, sexo e raça dos animais. O estudo epidemiológico detectou 111 animais com doenças de pele e destes, 20,7\% apresentavam demodicose. Posteriormente, amostras de soro foram obtidas de outros grupos de cães com demodicose, DA ou saudáveis, e analisadas quanto aos níveis de IgG e IgE específicos para Dp e Df, avidez de IgG a Dp por ELISA e proteínas específicas de Dp reconhecidas por IgE por immunoblot. Anticorpos IgG e IgE para $\mathrm{Dp}$ foram detectados em soros de grupos adicionais de cães com DA, demodicose ou saudáveis, com níveis mais altos de IgE para Dp na DA do que no soro de animais saudáveis. Níveis de IgG específicos para Df foram detectados, apesar serem menores em comparação com os detectados para Dp em soros de cães demodéticos, e também em cães saudáveis. A análise de immunoblot demonstrou detecção de IgE para proteinas de Dp em soros de cães com demodicose e DA; com forte reatividade para os antígenos de 72 e 116 $\mathrm{kDa}$ detectados por soros de cães com demodicose. No entanto, soros de cães saudáveis $>12$ meses de idade também apresentaram reatividade a essas bandas. Em conclusão, a detecção de anticorpos Dp-IgG e IgE específicos em soros de cães demodéticos indica exposição prévia e sensibilização aos ácaros, respectivamente, mais do que reatividade cruzada entre ácaros Demodex e antígenos Dp detectados por anticorpos caninos. Além disso, níveis de Dp-IgE específicos mais elevados encontrados em cães com DA, sugerem que esses anticorpos poderiam discriminar melhor cães com DA daqueles saudáveis ou mesmo demodéticos.

PALAVRAS-CHAVE: Cães. Demodex canis. Demodicose. Dermatophagoides pteronyssinus. IgG. $\operatorname{IgE}$.

\section{REFERENCES}

ALMEIDA, K. C.; SILVA, D. A. O.; GENARI-CARDOSO, M. L.; CUNHA-JÚNIOR, J. P.; ALVES, R.; YNOUE, L. H.; RESENDE, R. O.; SUNG, S. J.; TAKETOMI, E. A. Responses of IgE, IgG1 and IgG4 to concanavalin A-binding Blomia tropicalis antigens in allergic patients. Brazilian Journal of Medical Biological Research, v. 39, p. 1445-1454, nov. 2006. https://doi.org/10.1590/S0100-879X2006001100008

ARLIAN, L. G.; VYSZENSKI-MOHER, D. L.; GILMORE, A. M. Cross-reactivity between Sarcoptes scabiei and the house dust mite, Dermatophagoides farinae (Acari: Sarcoptidae and Pyroglyphidae). Journal of Medical Entomology, v. 25, p. 240-247, jul. 1988. https://doi.org/10.1093/jmedent/25.4.240

ARLIAN, L. G.; VUSZENSKI-MOHER, D. L.; AHMED, S. G.; ESTES, S. A. Cross-antigenicity between the scabies mite, Sarcoptes scabiei and the house dust mite, Dermatophagoides pteronyssinus. Journal of Investigative Dermatology, v. 96, p. 349-354, mar. 1991. https://doi.org/10.1111/1523-1747.ep12465257

ARLIAN, L. G.; BERNSTEIN, D.; BERNESTEIN, I. L.; FRIEDMAN, S.; GRANT, A.; LIEBERMAN, P.; LOPEZ, M.; METZGER, J.; PLATTS-MILLS, T.; SCHATZ, M. Prevalence of dust mites in the homes of people with asthma living in eight different geographic areas of the United States. Journal Allergy and Clinical Immunology, v. 90, p. 292-300, sep. 1992. https://doi.org/10.1016/S0091-6749(05)80006-5 
ARLIAN, L. G.; MORGAN, M. S. Serum antibody to Sarcoptes scabiei and house dust mite prior to and during infestation with S. scabiei. Veterinay Parasitology, v. 90, p. 315-326, jul. 2000.

https://doi.org/10.1016/S0304-4017(00)00251-X

BELlATO, V.; SARTOR, A. A.; SOUZA, A. P.; RAMOS, B. C. Ectoparasites in dogs from Lages municipality, Santa Catarina, Brazil. Revista Brasileira de Parasitologia Veterinária, v. 12, p. 95-98, 2003. BENSIGNOR, E.; CARLOTTI, D. N. Sensitivity patterns to house dust mites and forage mites in atopic dogs: 150 cases. Veterinary Dermatology, v. 13, p. 37-42, 2002. https://doi.org/10.1046/j.0959-4493.2001.00270.x

CHOI, W. P.; LEE, S.I.; LEE, K. W. Etiological and epidemiological features of canine dermatitis. Korean Journal of Veterinary Research, v. 40, p. 94-100, 2000.

EGLI, K. S.; SCHIESSL, B.; ROOSJE, P. J.; SEEWALD, W.; FORSTER, U.; PEEL, J. E.; WELLE, M. M. Evaluation of the usefulness of sensitization to aeroallergens as a model for canine atopic dermatitis in genetically predisposed Beagles. American Journal of Veterinary Research, v. 63, p. 1329-1336, sep. 2002. https://doi.org/10.2460/ajvr.2002.63.1329

FALK, E. S.; BOLLE, R. IgE antibodies to house dust mite in patients with scabies. British Journal of Dermatology, v. 103, p. 283-288, sep. 1980a. https://doi.org/10.1111/j.1365-2133.1980.tb07245.x

FALK, E. S.; BOLLE, R. In vitro demonstration of specific immunological hypersensitivity to scabies mite. British Journal of Dermatology, v. 103, p. 367-373, oct. 1980b. https://doi.org/10.1111/j.1365-

2133.1980.tb07258.x

FELIX, A. O. C.; GUIOT, E. G.; STEIN, M.; FELIX, S. R.; SILVA, E. F.; NOBRE, M. O. Comparison of systemic interleukin 10 concentrations in healthy dogs and those suffering from recurring and first time Demodex canis infestations. Veterinary Parasitology, v. 193, p. 312-315, mar. 2013. https://doi.org/10.1016/j.vetpar.2012.11.012

FERNANDEZ-CALDAS, E.; PUERTA, L.; MERCADO, D.; LOCKEY, R. F.; CARABALLO, L. R. Mite fauna, Der p I, Der f I and Blomia tropicalis allergen levels in a tropical environment. Clinical \& Experimental Allergy, v. 23, p. 292-297, apr. 1993. https://doi.org/10.1111/j.1365-2222.1993.tb00325.x

FERRER, L.; RAVERA, I.; SILBERMAYR, K. Immunology and pathogenesis of canine demodicosis. Veterinary Dermatology, v. 25, p. 427-e65, oct. 2014. https://doi.org/10.1111/vde.12136

GREEVE, J. H.; GAAFAR, S. M. Natural transmission of Demodex canis in dogs. Journal of the American Veterinary Medical Association, v. 148, p. 1043-1045, may. 1966.

HENSEL, P.; SANTORO, D.; FAVROT, C.; HILL, P.; GRIFFIN, C. Canine atopic dermatitis: Detailed guidelines for diagnosis and allergen identification. BMC Veterinary Research, v. 11, p. 196, aug. 2015. https://doi.org/10.1186/s12917-015-0515-5

HILLIER, A.; GRIFFIN C. E. The ACVD task force on canine atopic dermatitis (I): incidence and prevalence. Veterinary Immunology and Immunopathology, v. 81, p. 147-151, sep. 2001. https://doi.org/10.1016/S0165-2427(01)00296-3

JORGE-NETO, J.; CROCCE, J.; BAGGIO, D. Ácaros da poeira domiciliar da cidade de São Paulo. Nota previa. Revista brasileira de alergia e imunopatologia, v. 2, p. 140-145, 1980.

KEPPEL, K. E.; CAMPBELL, K. L.; ZUCKERMANN, F. A.; GREELEY, E. A.; SCHAEFFER, D. J.; HUSMANN, R. J. Quantitation of canine regulatory T cell populations, serum interkeukin-10 and allergenspecific IgE concentrations in healthy control dogs and canine atopic dermatitis patients receiving allergenspecific immunotherapy. Veterinary Immunology and Immunopathology, v.123, p. 337-344, jun. 2008. https://doi.org/10.1016/j.vetimm.2008.02.008 
KWOCHKA, K. W. Mites and related disease. Veterinary Clinics of North America: Small Animal Practice, v. 17, p. 1263-1284, nov. 1987. https://doi.org/10.1016/S0195-5616(87)50002-X

LAEMMLI, U. K. Cleavage of structural proteins during the assembly of the head of bacteriophage T4.

Nature, v. 227, p. 680-685, aug. 1970. https://doi.org/10.1038/227680a0

LAUBER, B.; MOLITOR, V.; MEURY, S.; DOHERR, M. G.; FAVROT, C.; TENGVALL, K.; BERGVALL, K.; LEEB, T.; ROOSJE, P.; MARTI, E. Total IgE and allergen-specific IgE and IgG antibody levels in sera of atopic dermatitis affected and non-affected Labrador- and Golden retrievers. Veterinary Immunology and Immunopathology, v. 149, p. 112-118, sep. 2012. https://doi.org/10.1016/j.vetimm.2012.05.018

LIAN, T. M.; HALLIWELL, R. E. Allergen-specific IgE and IgGd antibodies in atopic and normal dogs. Veterinary Immunology and Immunopathology, v. 66, p. 203-223, dec. 1998. https://doi.org/10.1016/S0165-2427(98)00199-8

LOWRY, H.; ROSENBOROUGH, N. J.; FARR, A. L.; RANDALL, R. J. Protein measurement with the Folin phenol reagent. Journal of Biological Chemistry, v. 193, p. 265-275, nov. 1951.

MARCOLINO, P. T.; SILVA, D. A.; LESER, P. G.; CAMARGO, M. E.; MINEO, J. R. Molecular markers in acute and chronic phases of human toxoplasmosis: Determination of immunoglobulin $\mathrm{G}$ avidity by western blotting. Clinical and Diagnostic Laboratory Immunology, v. 7, p. 384-389, may. 2000.

https://doi.org/10.1128/CDLI.7.3.384-389.2000

MARTINS, L. M.; MARQUES, A. G.; PEREIRA, L. M.; GOICOA, A.; SEMIÃO-SANTOS, S. J.; BENTO, O. P. House-dust mite allergy: mapping of Dermatophagoides pteronyssinus allergens for dogs by twodimensional immunoblotting. Postępy Dermatologii i Alergologii, v. 32, p. 73-81, apr. 2015. https://doi.org/10.5114/pdia.2015.48067

MASUDA, K.; TSUJIMOTO, H.; FUJIWARA, S.; KURATA, K.; HASEGAWA, A.; YASUEDA, H.; YAMASHITA, K.; DEBOER, D. J.; DE WEEK, A. L.; SAKAGUCHI, M. IgE sensitivity and cross-reactivity to crude and purified mite allergens (Der f1, Der f2, Der p1, Der p2) in atopic dogs sensitive to Dermatophagoides mite allergens. Veterinary Immunology and Immunopathology, v. 72, p. 303-313, dec. 1999. https://doi.org/10.1016/S0165-2427(99)00142-7

MASUDA, K.; SAKAGUCHI, M.; FUJIWARA, S.; KURATA, K.; YAMASHITA, K., ODAGIRI, T., NAKAO, Y., MATSUKI, N., ONO, K., WATARI, T., HASEGAWA, A.; TSUJIMOTOA, H. Positive reactions to common allergens in 42 atopic dogs in Japan. Veterinary Immunology and Immunopathology, v. 73, p. 193-204, feb. 2000. https://doi.org/10.1016/S0165-2427(99)00166-X

MAZRIER, H.; VOGELNEST, L. J.; THOMSON, P. C.; TAYLOR, R. M.; WILLIAMSON, P. Canine atopic dermatitis: Breed risk in Australia and evidence for a susceptible clade. Veterinary Dermatology, v. 27, p. 167-e42, jun. 2016. https://doi.org/10.1111/vde.12317

MONTEALEGRE, F.; QUIÑONES, C.; TORRES, N.; GOTH, K. Detection of serine proteases in extracts of the domestic mite Blomia tropicalis. Experimental and Applied Acarology, v. 26, p. 87-100, 2002. https://doi.org/10.1023/A:1020931221953

MUELLER, R. S. Treatment protocols for demodicosis: An evidence-based review. Veterinary Dermatology, v. 15, p. 75-89, apr. 2004. https://doi.org/10.1111/j.1365-3164.2004.00344.x

NAYAK, D. C.; TRIPATHY, S. B.; DEY, P. C.; RAY, S. K.; MOHANTY, D. N.; PARIDA, G. S.; BISWAL, S.; DAS, M. Prevalence of canine demodicosis in Orissa (India). Veterinary Parasitology, v. 73, p. 347-352, dec. 1997. https://doi.org/10.1016/S0304-4017(97)00125-8 
NUTTALL, T. J.; LAMB, J. R.; HILL, P. B. Characterisation of major and minor Dermatophagoides allergens in canine atopic dermatitis. Research in Veterinary Science, v. 71, p. 51-57, aug. 2001.

https://doi.org/10.1053/rvsc.2001.0485

OLIVEIRA, C. D.; LARSSON, C. E.; DE CAMARGO, M. M. Longitudinal assessment of T-lymphocyte subpopulations during generalized demodicosis in dogs and their relationship with remission. Veterinary Dermatology, v. 26, p. 18-22, feb. 2015. https://doi.org/10.1111/vde.12183

OLIVRY, T.; DEBOER, D. J.; GRIFFIN, C. E.; HALLIWELL, R. E.; HILL, P. B.; HILLIER, A.; MARSELLA, R.; SOUSA, C. A. The ACVD task force on canine atopic dermatitis: forewords and lexicon. Veterinary Immunology and Immunopathology, v. 81, p. 143-146, sep. 2001.

https://doi.org/10.1016/S0165-2427(01)00343-9

PARADIS, M. New approaches to the treatment of canine demodicosis. Veterinary Clinics of North America: Small Animal Practice, v. 29, p. 1425-1436, nov. 1999. https://doi.org/10.1016/S01955616(99)50136-8

PEREIRA, E. A. L.; SILVA, D. A. O.; CUNHA-JÚNIOR, J. P.; ALMEIDA, K. C.; ALVES, R.; SUNG, S. J.; TAKETOMI, E. A. IgE, IgG1, and IgG4 antibody responses to Blomia tropicalis in atopic patients. Allergy, v. 60, p. 401-406, mar. 2005. https://doi.org/10.1111/j.1398-9995.2005.00738.x

PRÉLAUD, P.; GUAGUÉRE, E. Sensitisation to the house dust mite, Dermatophagoides farinae, in dogs with sarcoptic mange. Veterinary Dermatology, v. 6, p. 205-209, 1995. https://doi.org/10.1111/j.1365-

3164.1995.tb00066.x

PUCHEU-HASTON, C. M.; JACKSON, H. A.; OLIVRY, T.; DUNSTON, S. M. HAMMERBERG, B. Epicutaneous sensitization with Dermatophagoides farinae induces generalized allergic dermatitis and elevated mite-specific immunoglobulin E levels in a canine model of atopic dermatitis. Clinical \& Experimental Allergy, v. 38, p. 667-679, apr. 2008. https://doi.org/10.1111/j.1365-2222.2008.02949.x

PUCHEU-HASTON, C. M.; BIZIKOVA, P.; EISENSCHENK, M. N.; SANTORO, D.; NUTTALL, T.; MARSELLA, R. Review: The role of antibodies, autoantigens and food allergens in canine atopic dermatitis. Veterinary Dermatology, v. 26, p. 115-e30, apr. 2015. https://doi.org/10.1111/vde.12201

RAVERA, I.; FERREIRA, D.; GALLEGO, L. S.; BARDAGÍ, M.; FERRER, L. Serum detection of IgG antibodies against Demodex canis by western blot in healthy dogs and dogs with juvenile generalized demodicosis. Research in Veterinary Science, v. 101, p. 161-164, aug. 2015.

https://doi.org/10.1016/j.rvsc.2015.06.011

REDDY, B. S.; SIVAJOTHI, S. CD4+ and CD8+ T cells in the peripheral blood of dogs affected with generalised demodicosis. Comparative Clinical Pathology, v. 25, p. 295-297, 2016.

https://doi.org/10.1007/s00580-015-2180-2

ROCHA, G. S.; AHID, S. M. M.; BEZERRA, A. C. D. S.; FILGUEIRA, K. D.; SANTOS, J. P. S. Mites frequency in dogs and cats at the city of Mossoró, Rio Grande do Norte, Brazil. Acta Scientiae Veterinariae, v. 36, p. 263-266, 2008. https://doi.org/10.22456/1679-9216.17297

RODRIGUEZ-VIVAS, R. I.; ORTEGA-PACHECO, A.; ROSADO-AGUILAR, J. A.; BOLIO, G. M. E. Factors affecting the prevalence of mange-mite infestations in stray dogs of Yucatán, Mexico. Veterinary Parasitology, v. 115, p. 61-65, jul. 2003. https://doi.org/10.1016/S0304-4017(03)00189-4

ROQUE, J. B.; O’LEARY, C. A.; KYAW-TANNER, M.; LATTER, M.; MASON, K.; SHIPSTONE, M.; VOGELNEST, L.; DUFFY, D. High allergen-specific serum immunoglobulin E levels in nonatopic West Highland white terriers. Veterinary Dermatology, v. 22, p. 257-266, jun. 2011. https://doi.org/10.1111/j.13653164.2010.00939.x 
SARIDOMICHELAKIS, M. N.; MARSELLA, R.; LEE, K. W.; ESCH, R. E.; FARMAKIS, R.; KOUTINAS, A. F. Assessment of cross-reactivity among five species of house dust and storage mites. Veterinary Dermatology, v. 19, p. 67-76, apr. 2008. https://doi.org/10.1111/j.1365-3164.2008.00654.x

SCOTT, D. W. Skin immune system and allergic skin diseases. In: SCOTT, D. N.; MILLER, W. H.; CRAIG, E. (Ed.). Griffin Muller and Kirk's Small Animal Dermatology. Philadelphia: W.B. Saunders, 2001. p. 543666. https://doi.org/10.1016/B978-0-7216-7618-0.50012-2

SEGUNDO, G. R.; SOPELETE, M. C.; TERRA, S. A.; PEREIRA, F. L.; JUSTINO, C. M.; SILVA, D. A.; TAKETOMI, E. A. Diversity of allergen exposure: implications for the efficacy of environmental control. Brazilian Journal of Otorhinolaryngology, v. 75, p. 311-316, mar-apr. 2009. https://doi.org/10.1016/S18088694(15)30796-5

SERRAVALLE, K; MEDEIROS JR, M. Ácaros da poeira domiciliar na cidade de Salvador-BA. Revista Brasileira de Alergia e Imunopatologia, v. 22, p.19-24, 1999.

SHIPSTONE, M. Generalised demodicosis in dogs, clinical perspective. Australian Veterinary Journal, v. 78, p. 240-242, apr. 2000. https://doi.org/10.1111/j.1751-0813.2000.tb11741.x

SILVA, D. A. O; SILVA, N. M.; MINEO, T. W. P.; PAJUABA, N. A. A.; FERRO, E. A. V.; MINEO, J. R. Heterologous antibodies to evaluate the kinetics of the humoral immune response in dogs experimentally infected with Toxoplasma gondii RH strain. Veterinary Parasitology, v. 107, p. 181-195, aug. 2002. https://doi.org/10.1016/S0304-4017(02)00132-2

SOUZA, C. P.; SCHISSLER, J. R.; CONTRERAS, E. T.; DOW, S. W.; HOPKINS, L. S.; COY, J. W.; ROSYCHUK, R. A. W.; HAWLEY, J. R.; LAPPIN, M. R. Evaluation of immunological parameters in pit bull terrier-type dogs with juvenile onset generalized demodicosis and age-matched healthy pit bull terrier-type dogs. Veterinary Dermatology, v. 29, p. 482-e162, dec. 2018. https://doi.org/10.1111/vde.12681

STURE, G. H.; HALLIWELL, R. E. W.; THODAY, K. L.; VAN DEN BROEK, A. H. M.; HENFREY, J. I.; LLOYD, D. H.; MASON, L. S.; FERGUSON, E. Canine atopic dermatitis: the prevalence of positive intradermal skin tests at two sites in the North and South of Great Britain. Veterinary Immunology and Immunopathology, v. 44, p. 293-308, feb. 1995. https://doi.org/10.1016/0165-2427(94)05306-D

SZCZEPANIK, M.; WILKOLEK, P.; TASZKUN, I. Canine atopic dermatitis and allergens responsible for development of sensitivity. Medycyna Weterynaryjna, v. 61, p. 305-308, 2005.

TERRA, S. A.; SILVA, D. A. O.; SOPELETE, M. C.; MENDES, J.; SUNG, S. J.; TAKETOMI, E. A. Mite allergen levels and acarologic analysis in house dust samples in Uberaba, Brazil. Journal of Investigation Allergology \& Clinical Immunology, v. 14, p. 232-237, 2004.

TOWBIN, H.; STSEHELIN, T.; GORDON, J. Electrophoretic transfer of proteins from polyacrylamide gels to nitrocellulose sheets: Procedure and some applications. Proceedings of the National Academy of Science of the United States of America, v. 76, p. 4350-4354, sep. 1979. https://doi.org/10.1073/pnas.76.9.4350

TSAI, Y. J.; CHUNG, W. C.; WANG L. C.; JU, Y. T.; HONG C. L.; TSAI, Y. Y.; LI, Y. H.; WU, Y. L. The dog mite, Demodex canis: Prevalence, fungal co-infection, reactions to light, and hair follicle apoptosis.

Journal of Insect Science, v. 11, p. 76, 2011. https://doi.org/10.1673/031.011.7601 